\title{
Corporate Governance at European Level: Romania - Study Case, Romanian Public Enterprises
}

\author{
Moşneanu Diana Georgiana \\ Administrative Science-Doctoral School, National School of Political Studies and Public Administration of Bucharest, Bucharest, Romania
}

Email address:

dianamosneanu@yahoo.com

\section{To cite this article:}

Moşneanu Diana Georgiana. Corporate Governance at European Level: Romania - Study Case, Romanian Public Enterprises. International Journal of Business and Economics Research. Vol. 10, No. 4, 2021, pp. 147-154. doi: 10.11648/j.ijber.20211004.15

Received: July 15, 2021; Accepted: August 6, 2021; Published: August 13, 2021

\begin{abstract}
The background: This paper present how the implementation of Corporate Governance in Romania's Public Enterprises is applied. The paper examines how the Key Performance Indicators are used to monitories the performance of the Public Enterprises, of the Board's performance and overall the Corporate Governance efficiency. Objective: Although the primary target of this paper is the improving of the Key Performance Indicators by introducing the sustainability indicator. The establishment of the sustainability indicator reflecting the competencies and clarifications of Board members from each public enterprises under the auspices of the Public Authority. Preliminary Studies: The Corporate Governance Codes, along with the Principles and Recommendations in this area, bring a reform in Europe. The research is based on the definition of Corporate Governance from the perspective of established scholars of the field, in which it is understood a concept of "corporate governance". Method: The methodology used in data collection, in consultation with the Annual Reports prepared by the Board of a public company, has led me to obtain key quantitative information that bases on the indicators used in the annual reporting and allows me to study new indicators for the future recruitment process. In order to obtain the necessary data for the formulation of the hypotheses, I approached the non-participatory observation in the conduct of investigations at the Romanian state companies. This matrix must also include a sustainability indicator, in addition to those that reflect the candidate's experience and training. Results: Depending on the current decisions, the recruitment process is lacking in adaptation of future trends in a developing society. This implies the adjustment of the present recruitment matrix, bringing to a form closer to the market demands and taking into account the transformations that takes place in the society. Implications: I am one of the specialist in the field of the implementation process of Corporate Government in Romania, so through self-questioning I will disseminate the information necessary for the study. Conclusion: A sustainable Corporate Governance is about efficiency, and must have a complex approach in the process of selecting candidates for the vacancies spots in the Board. By adopting a new selection criterion in addition to the existing ones, Corporate Governance conforms to the new trends of the society, such as sustainability trend. Sustainability in decision-making process becomes a strong point of "good Corporate Governance".
\end{abstract}

Keywords: Corporate Governance, Public Administration, Study Case, KPI

\section{Introduction}

The research motivation consists in outlining performance indicators at the level of Public Enterprises and their management in order to improve their efficiency. Thus, the objectives and the degree of fulfillment of the Performance Indicators are being pursued. These indicators are divided into two categories: financial - Financial Predictors [20] Notation Data used for calculation Positive values and nonfinancial [20] ones, reflecting the nature of the activity of the respective Enterprise. The criteria for choosing the operational and governance indicators are the importance of fulfilling the policy objectives of the Government and the Tutelary Public Authority, in accordance with the legislation in force, and having favorable results in the economic sector, aiming to obtain them, for each Public Enterprise, corresponding to the domain of the activity in which the respective enterprise operates. [17]

"The monitoring of the financial and non-financial indicators, annexed to the contractual mandates of the public enterprises, operating under the authority of the Ministries" [1] establishes the manner of carrying out the activities and 
the processes of approval at the level of the Ministry, in order to achieve the proposed goal for actual procedure. They have to insurance stability and professional management for the affiliate Ministry units by annual report [20].

According to the European Corporate Governance Institute, Corporate Governance [25] represents the process of "empowering Enterprises and Institutions by balancing economic and social objectives with community aspirations at the level of the European Union and individual aspirations at the level of each Member State." [24]

Establishing an adequate Governance framework is based on strengthening economic performance, predominantly in developing countries, with a fundamental importance in discouraging fraud and mismanagement. [13]

Corporate Governance is a state-of-the-art tool in public enterprise management, focusing on transparency and guidance for administrators towards a new dimension of risk management that the Enterprise itself exposes. [14]

To be successful, businesses need to be aware of the fact that different strategic contexts require different value indicators [7]. This means that it is important to establish value measures. [9] This implies the existence of a balanced data sheet, which should cover these measures and be elaborated by introducing and approving the management of the enterprise. It should also be mentioned that the public sector has different value factors / indicators than the private sector. [12] In the public sector, measures such as compliance with legal provisions and due diligence take precedence over financial measures, such as cost-effectiveness. There is an appetite for regulators and investors for strong and profound changes in governance. Surveillance authorities, oversight bodies and management teams have begun implementing only $40 \%$ of these reforms until present. [11]

Corporate Governance is defined by Government Emergency Order No. 109 / 2011 [20] - internal Romanian law, as the set of rules by which a company is managed and controlled. Its role, being designated by the main actors involved internal - the directors of a company, the executive and the non-executive, who must be independent and have objectivity, on the one hand,

and the external actors - the shareholders who appoint the directors and which they then pursue to defend their interests and set motivational packages for executives, according to alignment with the company's goals, investing less in their monitoring activity. This is the fundamental Law in Romanian Corporate Governance.

The means to achieve these performance monitoring objectives need to be continually improved, especially in Romania, where ministries with the help of the World Bank initiated in the majority state-owned companies the implementation of a corporate governance framework and where the need for guidance has become essential, support that long-term need for Public Enterprises, due to subsidy dependence or inability of Enterprises to get out of the stalemate.

More and more governments around the world are improving their governance practices in order to increase their competitiveness and the economy, playing an essential role in streamlining management activity. [6]

Corporate Governance is the system of principles, policies, procedures and responsibilities clearly defined and used by stakeholders to overcome conflicts of interest in corporate form [16]. The corporate governance framework [18] must promote transparent and efficient markets, respect the rule of law, and clearly articulate the division of responsibilities between the various supervisory, regulatory and enforcement authorities [20].

The public authority coordinates the entire process of state ownership, reorganization, privatization, and postprivatization of companies, subsidiaries, and entities that operate in its portfolio, once the internal legislation on corporate governance has been established in public enterprises. [15] The Tutelary Public Authority, through his empower its attributed by the Government, seeks to develop corporate governance inside of his activity, based on good practices resulting from projects and actions together with partners such as the World Bank and the European Investment Bank. Specific Emergency Ordinances designate the structure that authority has over public enterprises as a tutelage public authority and his responsibilities is to ensure transparency, supervision and control over the top management of subordinate public enterprises. [12]

Thus, research questions are generated:

1. How the recruitment and selection process is made? The current criteria is enough?

2. How effective is the exercise of shareholder functions on behalf of the state? is there compatibility?

3. Is there transparency in coordinating the exercise of the functions specific to shareholders? ensure transparency of the state in the supervision process?

4. Is the monitoring of the board of directors of the public enterprises directly ensuring that public enterprises operate on the basis of the principles of economic efficiency and profitability and sustainability?

These questions have the answer to the responsibility of the state, which implies a consistency in its position as an active owner, found in the form of recommendations of the Organization for Economic Cooperation and Development [4]. I obtained a performance matrix for the recruitment and selection process of the candidates for future positions in a Public Enterprises' Board, by using the example from Romanian Norms Decision HG 722/2016 [8], and reinterpretation of the selection criteria table. A matrix is already used in the recruiting process of the candidates, exposes information about the candidate's experience and reflects "the specific activity of the public enterprise" [1], but without a clear criteria to reflect how to make decisions as an administrator, that involves the future consequences is still missing from the criterial point of view.

There are many definitions of Corporate Governance and with time passing by, new form of Corporate Governance emerged: e-governance. Here are some examples:

According to "OECD Principles of Corporate Governance, 2004"4, Retrieved, Tricker, and Adrian [3]: "Corporate 
governance includes the processes through which corporations' objectives are set and pursued in the context of the social, regulatory and market environment. These include monitoring the actions, policies, practices, and decisions of corporations, their agents, and affected stakeholders. Corporate governance practices can be see as attempts to align the interests of stakeholders." A corporate collapse typically involves the insolvency or bankruptcy of a major business enterprise. A corporate scandal involves alleged or actual unethical behavior by people acting within or on behalf of a corporation.

"Governance structures and principles identify the distribution of rights and responsibilities among different participants in the corporation (such as the board of directors, managers, shareholders, creditors, auditors, regulators, and other stakeholders) and include the rules and procedures for making decisions in corporate affairs."[6].

And the term of Governance according to Bevir Mark (2012), is refering to "all processes of governing, whether undertaken by a government, market, or network, whether over a family, tribe, formal or informal organization, or territory, and whether through laws, norms, power or language. Governance differs from government in that it focuses less on the state and its institutions and more on social practices and activities." [5]

In the Note "Public Administration Reform", (PAR), we find "focuse on the executive branch of government". It takes an approach that is informed by recent thinking in the realm of public management, which borrows from a number of other areas of research as well as from the private sector to find new solutions, places the public sector in its cultural and political environment, and sees the role of public manager as an active and motivating agent. Nevertheless, it also recognizes that many of the more radical reforms attempted in countries such as New Zealand and the United Kingdom are too ambitious and present real dangers for most developing countries; simply getting the public administration to execute the will of its political masters is often a challenge in itself (...). The Note focuses on the executive branch of government. It does not include the administration of the other branches of government, including the legislative and the judicial branches, which share some of the issues of the executive branch, but are nevertheless distinguished in their particulars. It takes an approach that is informed by recent thinking in the realm of public management, which borrows from a number of other areas of research as well as from the private sector to find new solutions, places the public sector in its cultural and political environment, and sees the role of public manager as an active and motivating agent. Nevertheless, it also recognizes that many of the more radical reforms attempted in countries such as New Zealand and the United Kingdom are too ambitious and present real dangers for most developing countries; simply getting the public administration to execute the will of its political masters is often a challenge in itself. Obviously, a practice note on PAR cannot tackle all these issues. In line with UNDP's approach to Democratic Governance, some of these very complex elements of PAR (decentralization, anti-corruption, Egovernance and access to information) will be treated in separate Practice Notes, or are indeed considered separate sub-practices. Other important issues will be addressed in Primers (e.g. Public Administration in Crisis Countries, the Impact of HIV/AIDS on Public Administration in Worst Affected Countries, Gender Mainstreaming in Public Administration Reform and others) [19].

So, we can see the new area of governance and its an example of sustainable governance providing useful tools like electronic systems. This idea of governance is presented as:

"Corporate governance is one of the basic elements of market mechanism based on competition. It is directly leans on democracy development and rule of law. Corporate governance depends of cooperation between private and public sector that want to accomplish two aims: competitive market system and democratic society that is based on the rule of law. This is not only relevant for developing countries; it is a universal issue that impacts the openness, credibility and values of one society. Corporative governance depends directly of reliable legal system and norms of business behavior." [17].

This paragraph above, shows how important is the development of new ways of corporate governance to cooperate with the new trends in the private sector, as well is in the public sector.

"One cannot overstate the fact that corporate governance is a continuous process. At each stage of governance improvements, a company must continue to reflect on what its new needs are and what new opportunities can be derived from its governance model. This is particularly true as the business landscape and developments in the concept of good corporate governance continue to evolve." [18].

\section{Methodology}

\section{Presentation of the Work}

This paper work proposes the development of simple, uncooperative support mechanisms for the implementation of corporate governance in the public sector in Romania, creating a way of working, facilitating the adaptation of Romanian Public Enterprises to the new requirements in this field, also facilitating the work of the Corporate Governance Structures. The paper addresses all those who are interested in the applicability of Corporate Governance.

Argument: From the perspective of the competences conferred by the provisions of the Romanian domestic legislation and from the perspective of European legislation regarding corporate governance, at present, the structures of corporate governance in the public sector in Romania deal only with the monitoring of the financial and economic performance indicators, reported annually through the Administrators' Report [20]. In my opinion, the monitoring of only some indicators is insufficient because it does not fully undertake the activity of the public enterprise, which 
has specific activities that are reflected in the operational indicators. These indicators are of a technical nature which gives the opportunity to have a broad picture of the position on the competitive market in terms of the niche in which it operates, as it is necessary to take into account these indicators specific to the activity of the public enterprise, having a direct impact and commensurable on the achievement of the targets proposed by the administrators of the board of directors and by the director of the public enterprise.

\section{Results}

\subsection{Study of Performance Indicators Applicable in Public Enterprises}

Starting from the definition in OECD [4] principles and continuing with the corporate governance attributes in terms of the principles that define it and considering the need to report the existing situation of a company / public enterprise, financial audit is the main tool for applying corporate governance codes.

The financial results of a company or public enterprises, in accordance with International Accounting Standards (IAS) [22], may be financial performance in the form of performance indicators that each company / enterprise must publish in order to inform those shareholders or the ordinary citizen.

These performance indicators may be financial or nonfinancial. According to IAS / IFRS approaches, financial performance is understood to mean the income, expenses and financial results of an economic entity. Information on these financial structures is mainly provided by the Profit and Loss Account, but some of the explanatory notes come to supplement the entity's performance information. Referring here at least to the compulsory explanatory notes to be drafted according to the accounting regulations in force (Analysis of the operating result) [21].

International Financial Reporting Standards [22] (known under IFRS as the International Financial Reporting Standards) are a set of accounting standards. They are currently issued by the International Accounting Standards Board (IASB). Many of the standards that are part of IFRS are known under the old International Accounting Standards (IAS).

The IASs were issued between 1973 and 2001 by the International Accounting Standards Committee [23] (IASC). In April 2001, the IASB adopted all IAS standards and then continued their development. The new standards bear the name of IFRS.

OECD - Organization for Economic Cooperation and Development [4].

\subsection{Z Indicators Used in the Annual Reporting of Public Enterprises}

In the Annual Activity Report of Public Enterprises [20], through Public Enterprises, we refer only to Publicly
Controlled Public Enterprises, Public Enterprises operating under the authority of the Ministry, (Tutelary Public Authority). And the proposed case study is the Minster, where concretely the annual "reporting of enterprise managers is analyzed by exemplifying and collecting existing public statistical data" [10].

\subsection{Transparency}

The Annual Report of the Enterprise Manager [20] ensures the transparency of the work and good practices applied during one year of the mandate.

From the point of view of free access to information of public interest, the Public Enterprises are assimilated to the category of public institutions and have the obligation to ensure the transparency of the activity, carried out by the ex officio. The communication of certain information of public interest, by answering the requests, are providing the public interest information, except the information according to the legal regulations in force. Keeping the recruiting process of administrators and directors [6] more rapid by adoption of measures, corporate governance is defined as a "set of procedures" [20] used owners, provides to stakeholders an overview of risk and management control procedures. Monitoring organizational risks and ensuring that these controls diminish the risks contribute directly to achieving the goals and maintaining the value of the organization. "According to the Organization for Economic Co-operation and Development [4], corporate governance specifies the distribution of the rights and responsibilities of the different categories of person involved in the company: administrators, directors, shareholders and other categories, and establishes the rules and procedures for making decisions about a company's business." [4]

Strengthen the financial discipline of public enterprises by implementing the recommendations made by independent auditors in the annual audit reports. Timely programming of the audit by concluding a contract, in accordance with the legal provisions, with an independent auditor so that the audit activity is carried out in optimal conditions and the audit evidence is sufficient and adequate. Restructuring of the national companies by approving merger projects through the absorption of subsidiaries, subject to opportunity and efficiency from a technical and economic point of view and in accordance with the legal provisions.

Some of these financial indicators can be selected as predictors of models for predicting corporate scoring over a short prediction horizon (1-3 years). Agreed methods of enterprise analysis are economic and fictional indicators, which give shareholders the opportunity to form an image of the evolution of the Enterprise. That is why I have proposed to select a series of skeleton indicators, becoming a small guide to the transparency of a business. Thus, strategic planning can be achieved that substantially improves Corporate Governance in the case of companies with majority state capital in Romania, being also an objective of the Romanian state. Next, the predictive financial indicators (Financial Predictors - Notation Data used for calculation 
Positive values), used in the models like Annual Administrator Report [20].

The categories of the financial indicators used in the models are:

liquidity, solvency, profitability, activity. The selection of the four categories is based on their popularity in the literature, each category having the following features:

The first category - liquidity - the analysis of a company's liquidity measures the company's ability to pay its short-term liabilities, being used when firms have cash problems;

The second category - solvency - the solvency analysis of a firm expresses the ability of a firm to make payments in a timely manner over time;

The third category - profitability - the analysis of a firm's profitability indicates information about the efficiency with which a company uses its own resources to generate profit;

The fourth category - activity - analysis of a company's activity provides information about the course of cash inflows and outflows and the ability of the firm to control its core business.
The indicators used in the Enterprise valuation are needed to draw an image in front of the shareholders of the respective Enterprise. 'The selection of indicators' [8] is included on the agenda of a general meeting of shareholders meeting, convened by the board of directors, board of directors submit to the shareholders the proposal of performance indicators, accompanied by an 'elaborated justification' [20]. It will motivate how these indicators reflect the objectives of the Management Plan and the expectations of the shareholders expressed in 'the Letter of Expectations' [20].

\subsection{Key Performance Indicators in a Recruitment Process}

The R. A. C. I. Matrix [25]

What is a RACI matrix? The RACI matrix is a responsibility assignment chart that identifies the key roles and responsibilities in the recruitment process during the elaboration of the Long List [20], which makes easier the selection process of the candidates.

Table 1. The R. A. C. I. MATRIX.

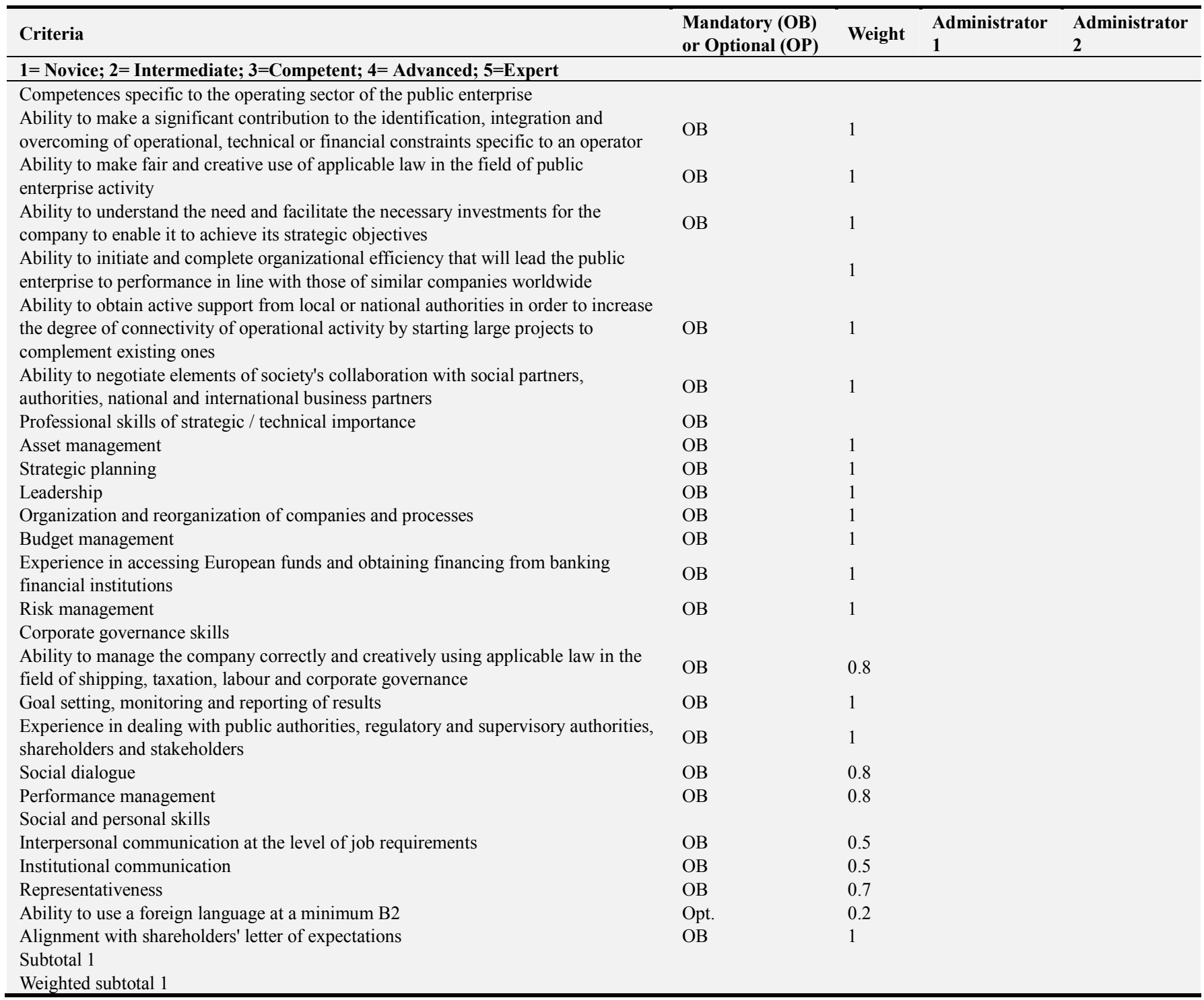




\begin{tabular}{|c|c|c|c|c|}
\hline Criteria & $\begin{array}{l}\text { Mandatory (OB) } \\
\text { or Optional (OP) }\end{array}$ & Weight & $\begin{array}{l}\text { Administrator } \\
1\end{array}$ & $\begin{array}{l}\text { Administrator } \\
2\end{array}$ \\
\hline \multicolumn{5}{|l|}{ 1= Novice; $2=$ Intermediate; 3=Competent; 4= Advanced; 5=Expert } \\
\hline Good personal and professional reputation & $\mathrm{OB}$ & 0.5 & & \\
\hline Independence & $\mathrm{OB}$ & 0.5 & & \\
\hline Entrepreneurial spirit & $\mathrm{OB}$ & 0.5 & & \\
\hline Vision & OB & 0.5 & & \\
\hline Dynamism & $\mathrm{OB}$ & 0.5 & & \\
\hline Team Spirit & OB & 0.5 & & \\
\hline \multicolumn{5}{|l|}{ Subtotal 2} \\
\hline \multicolumn{5}{|l|}{ Weighted subtotal 2} \\
\hline Knowledge of the Romanian language & $\mathrm{OB}$ & 0.5 & & \\
\hline Higher education completed & OB & 0.5 & & \\
\hline Postgraduate studies & $\mathrm{OB}$ & 0.5 & & \\
\hline Full exercise capacity & Opt. & 0.5 & & \\
\hline No documents in the criminal record & OB & 0.5 & & \\
\hline $\begin{array}{l}\text { Minimum } 5 \text { years of experience in the administration or management of some } \\
\text { entities, legal entities that carry out activities specific to the sector of activity of the } \\
\text { public enterprise. }\end{array}$ & OB & 1 & & \\
\hline $\begin{array}{l}\text { Competences in the field of sustainability / involvement in business sustainability } \\
\text { projects }\end{array}$ & $\mathrm{OB}$ & 1 & & \\
\hline He has not been dismissed in the last 7 years & $\mathrm{OB}$ & 0.5 & & \\
\hline It is not in a situation of incompatibility & & 0.5 & & \\
\hline It is not in conflict of interest & $\mathrm{OB}$ & 0.5 & & \\
\hline \multicolumn{5}{|l|}{ TOTAL } \\
\hline \multicolumn{5}{|l|}{ Weighted total } \\
\hline Ranking & & & & \\
\hline
\end{tabular}

Table 1. Continued.

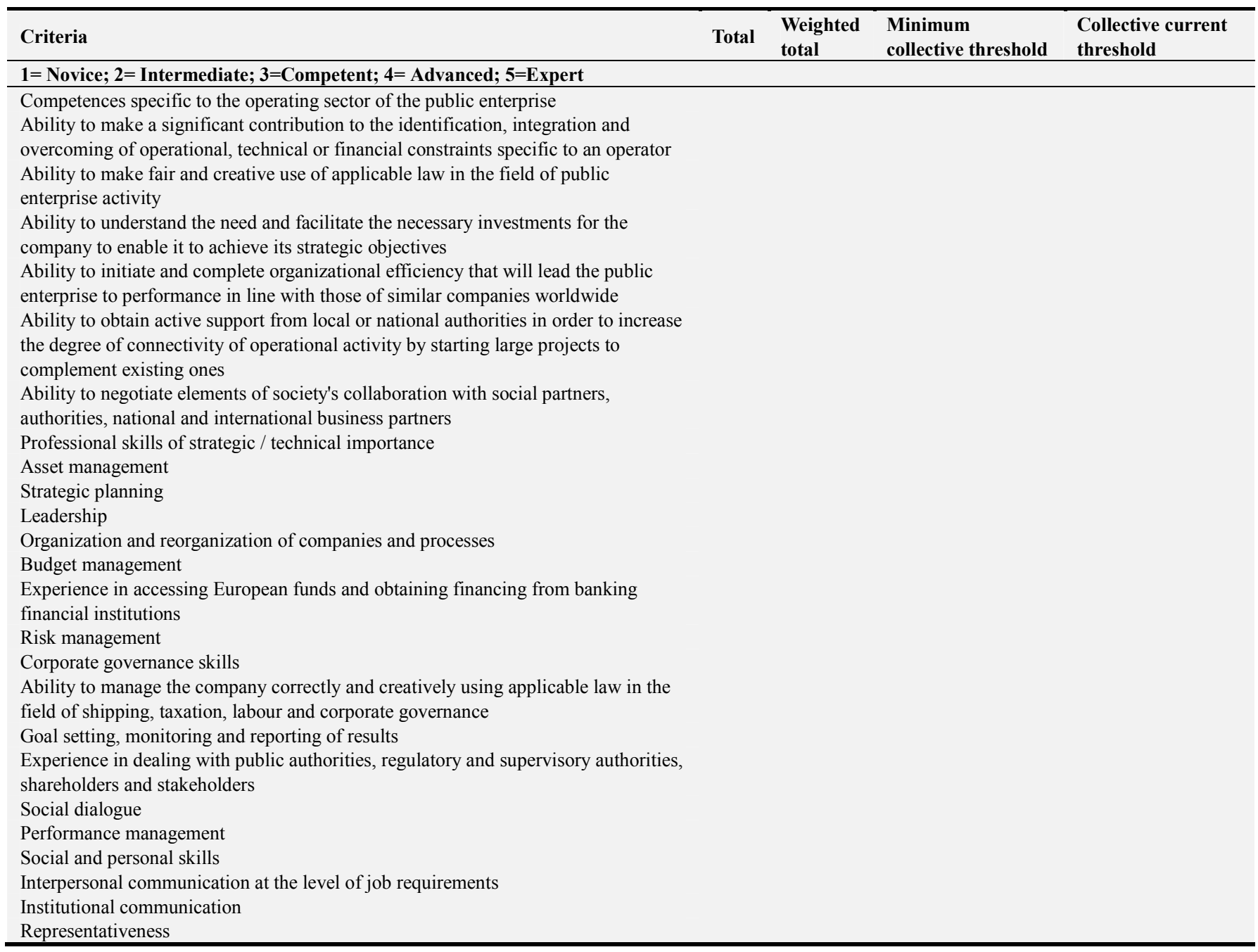




\begin{tabular}{|c|c|c|c|c|}
\hline Criteria & Total & $\begin{array}{l}\text { Weighted } \\
\text { total }\end{array}$ & $\begin{array}{l}\text { Minimum } \\
\text { collective threshold }\end{array}$ & $\begin{array}{l}\text { Collective current } \\
\text { threshold }\end{array}$ \\
\hline 1= Novice; $2=$ Intermediate; $3=$ Competent; $4=$ Advanced; 5=Expert & & & & \\
\hline $\begin{array}{l}\text { Ability to use a foreign language at a minimum B2 } \\
\text { Alignment with shareholders' letter of expectations } \\
\text { Subtotal } 1 \\
\text { Weighted subtotal } 1 \\
\text { Good personal and professional reputation } \\
\text { Independence } \\
\text { Entrepreneurial spirit } \\
\text { Vision } \\
\text { Dynamism } \\
\text { Team Spirit } \\
\text { Subtotal } 2 \\
\text { Weighted subtotal } 2 \\
\text { Knowledge of the Romanian language } \\
\text { Higher education completed } \\
\text { Postgraduate studies } \\
\text { Full exercise capacity } \\
\text { No documents in the criminal record } \\
\text { Minimum } 5 \text { years of experience in the administration or management of some } \\
\text { entities, legal entities that carry out activities specific to the sector of activity of the } \\
\text { public enterprise. } \\
\text { Studies in the field of sustainability / involvement in business sustainability projects } \\
\text { He has not been dismissed in the last } 7 \text { years } \\
\text { It is not in a situation of incompatibility } \\
\text { It is not in conflict of interest } \\
\text { TOTAL } \\
\text { Weighted total } \\
\text { Ranking }\end{array}$ & & & & \\
\hline
\end{tabular}

Source: Own reinterpretation of the selection matrix taken from "Decision no. 722 of September 28, 2016 for the approval of the Methodological Norms for the application of certain provisions of the Government Emergency Ordinance no. 109/2011 on the corporate governance of public enterprises" for my empirical study.

NOTE: "Competences in the field of sustainability / involvement in business sustainability projects" is my proposal of a new criteria that can deal into innovative reorganization of matrix.

\section{Conclusions}

The procedure is used by the corporate governance structure of the public tutelage authority, that monitors the financial and non-financial performance indicators attached to the mandate contracts of the directors of public enterprises, operating under the authority of the ministries, keeping records of mandate and contracts between the administrators of the public enterprises and the Public Authority as well as the directors of the companies, coordinating the annual review process, and meeting the objectives of the management plans to ensure that the principles of economical efficiency and profitability as an autonomous administration operation.

In conclusion, within corporate governance concepts, a central place is the transparency of financial-accounting information, because it is the basis of the entire decisionmaking process. For these reasons, the financial-accounting information must achieve a certain quality and contribute to the efficient administration of the organization and the increase of its market value.

In managing a company, the lead actor is the general manager. It plays an important role in creating value and ensuring the company's performance.

The quality of the information contained in the financial reports has increased in all countries, from one period to the next, as a result of internal and external pressures by international regulatory bodies, which are largely in line with OECD principles [4].

In organizational management, recent realities confirm that substantial progress has been made in the countries of South East Europe, including Romania, which has helped to improve the legal and regulatory framework against abuse, which is why I proposed to bring in the foremost importance of this field and studying new tools for the public sector in Romania, simple support mechanisms, uncompromising, contributing to the development of Corporate Governance.

\section{References}

[1] Corporate Governance in the Digital world, Moşneanu Diana, 2020, Proceedings of the International Conference on Business Excellence, Sciendo, vol. 14 (1), pages 333-342, July.

[2] Term used in Cadbury Report, Lord Cadbury, UK (1992).

[3] Essentials for Board Directors: An A-Z Guide, Bloomberg Press, New York, 2009, ISBN 978-1-57660-354-3, Retrieved 2013-05-18, Tricker, Adrian.

[4] OECD Principles of Corporate Governance, 2004. 
[5] Governance: A very short introduction. Oxford, UK: Oxford University Press. ISBN 9780191646294 , Bevir, Mark (2012).

[6] The Corporate Governance of Iconic Executives. SSRN 2040922, Lin, Tom C. W. (Aug 11, 2011).

[7] E-government implementation in Romania. From national success to international example. Ovidiu Stoica, Academia.edu accesed on 1 june 2021.

[8] Decision HG no. 722 of September 28, 2016 for the approval of the Methodological Norms for the application of certain provisions of the Government Emergency Ordinance no. $109 / 2011$ on the corporate governance of public enterprises.

[9] Alexandru, Ioan şi Matei, Lucica. (2000). Servicii publice. Bucureşti: Editura Economică.

[10] Boulouis, Jean. (1964). "La Decentralisation”. Publications des annals de la Faculte de Lettres. Aix-en- Provence: Edition Ophrys. Nouvelle Serie no. 44.

[11] COMMISSION EUROPEAN, COMMISSION WORKING DOCUMENT: Country Report of 2018 on Romania.

[12] COMMUNICATION FROM THE COMMISSION TO THE EUROPEAN PARLIAMENT, THE COUNCIL, THE EUROPEAN CENTRAL BANK AND THE EUROGRUP European Semester 2018: Assessment of progress in the field structural reforms, prevention and correction of macroeconomic imbalances, as well and the results of the indepth reviews carried out under Regulation (EU) no. $1176 / 2011$.

[13] Managing Sustainability risks and opportunities in the financial services sector Non-Executive Directors Briefing, May 2012 Phil Case PwC UK.

[14] Roy Girasa. "Corporate Governance and Finance Law", Springer Science and Business Media LLC, 2013.

[15] "International Debt", Springer Science and Business Media LLC, 2013.
[16] Robert W. McGee. "Chapter 1 Corporate Governance in Transition Economies", Springer Science and Business Media LLC, 2009.

[17] Development of Corporate Governance under the privatization process in Montenegro, Petrar IvanovicDirector Center for Entrepreneurship and Economic Development (CEED), Podgorica, Montengro. Prepared for the: First South East Europe Corporate Governance Round Table. Organised By: OECD and The World Bank Hosted By: The National Securities Commission and the Bucharest Stock Exchange Bucharest, 20-21 September 2001.

[18] Practical Guide to Corporate Governance, Implementing Governance, pp. 162.

[19] United Nations Capital Development Fund, pp. 2.

[20] Govermental Emergency Orders: O. U. G. 109/2011 on the corporate governance of public enterprises.

[21] Minister of Romanian Public Finance Order no 1752/2005: "Analysis of the operating result".

[22] International Financial Reporting Standards (known under IFRS as the International Financial Reporting Standards) are a set of accounting standards. They are currently issued by the International Accounting Standards Board (IASB). Many of the standards that are part of IFRS are known under the old International Accounting Standards (IAS).

[23] The IASs were issued between 1973 and 2001 by the International Accounting Standards Committee (IASC). In April 2001, the IASB adopted all IAS standards and then continued their development. The new standards bear the name of IFRS.

[24] European Corporate Governance Institute, Corporate Governance, European Union, ECGI- European corporate governance institute.

[25] Websites: www.gov.ro; www.anfp.gov.ro; www.pna.gov.ro; www.transparency.org.ro; consulted at june 2021. 